\title{
Influence and Prospect of Chinese Hog Futures- Live Hog Industry Perspective
}

\author{
Yi Guo ${ }^{1 *}$, Jiajun $\mathrm{Luo}^{2}$, Ruining $\mathrm{Zhu}^{3}$, Chengzong $\mathrm{Li}^{4}$

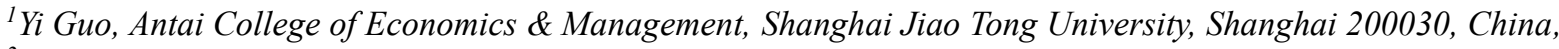 \\ ${ }^{2}$ JiaJun Luo, College of Finance, NanKai University, Tianjin 300350, China \\ ${ }^{3}$ Ruining Zhu, Vanke Meisha Acadamy, Shenzhen 518000, China \\ ${ }^{4}$ Chengzong Li (Jason) John. F Kennedy Catholic Preparatory School, Somers, NY state 10589, US \\ *luckyyyyy@sjtu.edu.cn
}

\begin{abstract}
The Dalian Commodity Exchange opened the hog futures market on 8th Jan, 2021 to smooth out price swings in Chinese pork markets. This paper aims to discuss the influence and prospect of such futures in China. The work introduces technical contract details and analyzes hog futures' potential benefits to the total supply chain of hog industry. Using VAR model to build interactions between prices of major products along the supply chain, the paper tests the relevance between these product prices and figures out the market anomaly of a too sharply downward live hog prices after issue of the contract through counterfactual prediction. This paper concludes that such inefficiency comes from scattered structure of hog breeding industry and introduces insurance as a tool to solve it. The general approach should give a clear picture of the contract's prospect in the future.
\end{abstract}

Keywords: hog futures, live hog industry, hog price prediction, pig cycle

\section{INTRODUCTION}

On $8^{\text {th }}$ Jan, 2021, the hog industry begins to trade in Dalian Commodity Exchange as the first type of futures to adopt live delivery. The unprecedented transaction form aims to deal with fluctuations in hog prices due to supply and demand mismatch caused by the long growing up process of hogs.

Pigs are the largest valuable agricultural and sideline products in China, with a market scale of nearly one trillion yuan. The live pig industry chain is centered on the live pig breeding industry and interact closely with other industries in the supply chain, including the slaughter houses and crop growing farms. Launching live pig futures is an important measure for China's futures market to serve the development of the real economy.

The paper aims to analyze the influence and prospect of the hog futures. Whether the futures are functioning well as it aims to do and how can the current problems be solved to let them develop further in the future is in the center of discussion.

First, the paper looks into the story and challenges before the issue and introduces the careful design of technical details of contracts. Then we analyze what potential benefits can the hog futures bring to all the participants of hog supply chain, even including the government in China. Following this analysis, our paper tests through empirical analysis about interactions between product prices along the supply chain. Using VAR model estimated from historical data, we predict the hog price without the influence of hog futures and use that curve to make comparison with the curve in reality. We find that hog futures didn't playing its role well in the past few months for certain reasons. We attribute such failure to the feeder structure in China and propose a very effective mode as a solution during the transition time from many scattered small-scale farms to several concentrated big companies that raise pigs.

The paper gives a clear picture of the basic function of the futures, its impact now and expectation in the future. With such suggestions, we hope the hog futures can

serve as a tool for risk management of the whole supply chain and stabilize the hog price more effectively. 


\section{THE DEBUT OF HOG FUTURES IN CHINA}

\subsection{Discussions before the Issue of China's Hog Futures}

In 2001 Dalian board of trade have a plan to issue the hog future in China. In March 2006, the general manager of Dalian Commodity Exchange (DCE) proposed the proposal of hog futures. However, at the first session of the eleventh National People's Congress in March 2008 the Li Zhengqiang, then party secretary and chairman of the Board bring doubts about the live delivery. In 2019 the COVID-19 slowed down the process of issue and the plan has been delayed. Finally, on January 8, 2021, the DCE issued the hogs futures officially. It is China's first live animal futures and the largest animal husbandry product futures.

During such process, two major problems are in discussion[1].

\section{- Decide Underlying Asset}

Underlying subjects of transaction is in detailed research. Before July 2008, the DCE proposed three schemes including pig carcass, live hogs and piglets.Before April, 2009 the DCE overcomes challenges, and is ready to take live hogs as the underlying asset. But diseases of live hogs forces them to reconsider scheme of pig carcass.

Piglets are the first to be voted down because it's hard to control the quality of delivery and price of them violates too drastically. With the futures trading based on pig carcass, there are a series of problems in quality standards, free market circulation, and supportive cold chain logistics. In this regard, live hogs win the final discussion as the subject linking the whole supply chain of the hog industry in 2012.

\section{- Decide Delivery Method}

The delivery of hogs is now limited to physical delivery. The Dalian Commodity Exchange has researched on cash delivery used by foreign hog related futures for many years, but still decide to defer such implementation. The core of cash delivery is the way to decide basic price of settlement, that is, the benchmark settlement price agreed by both buyers and sellers to calculate the profit and loss of the due contract. So the futures market which adopts cash delivery has a developed and concentrated spot market, which makes calculation if commodity price index easy. However, in China, the domestic pig breeding area is scattered, diverse, does not have a perfect spot market and the information is not smooth. How to scientifically calculate the delivery benchmark settlement price will be a difficult problem.

Referring to Chicago Mercantile Exchange(CME), which holds the most active lean pig futures in America, it is seen to have changed from physical delivery to cash delivery. Such conversion is under the condition when the hog industry exclude most of the wholesale markets and feeders directly sell hogs to slaughter houses. Moreover, transportation cost is saved and debates on hog quality and possibilities of forced positions can be avoided[2]. China is on the way.

\subsection{Technical Details of the Hog Futures}

Table 1. Contract Details[3]

\begin{tabular}{|c|c|}
\hline Trading Varieties: & Live hog \\
\hline Listed Exchange: & Dalian Commodity Exchange \\
\hline Trading Unit & 16 tons/board lot \\
\hline Quotation Unit: & Yuan (RMB)/ton \\
\hline Minimum Price Change: & 5yuan/ton \\
\hline Transaction Hour: & $\begin{array}{l}\text { Every Monday to Friday from 9:00 to } 11: 30 \text { in the morning and } 13: 30 \text { to } \\
15: 00 \text { in the afternoon and other times announced by the exchange }\end{array}$ \\
\hline Last Trading Day: & The fourth-to-last trading day of the contract month \\
\hline Contract Delivery Month & January, March, May, July, September, November \\
\hline Delivery Method: & Physical delivery \\
\hline Delivery Date: & The third trading day after the last trading day \\
\hline Delivery Location: & $\begin{array}{l}\text { The designated delivery warehouse of the Dalian Commodity Exchange } \\
\text { for pigs, and the designated delivery place for the car board }\end{array}$ \\
\hline
\end{tabular}




\section{Trading Margin Level:}

Transaction Limit:

Transaction Fee:

Delivery Fee:

Storage Fee:
The hog futures contract is down about $20 \%$ from the listed benchmark price

Non-futures company members or clients' single-day open positions shall not exceed 500 lots. The single-day open position refers to the sum of the number of open positions for buying and selling on all monthly contracts of the non-futures company members or clients on that day

The transaction fee is two ten thousandths of the transaction amount, and the intraday transaction fee is four ten thousandths of the transaction amount

1 yuan/ton

Store 5 yuan/day

Table 2. Transaction Code of the Live Hog Futures[3]

\begin{tabular}{|l|l|}
\hline Transaction Code & LH \\
\hline LH2109 & 30680yuan (RMB)/ton \\
\hline LH2111 & 29680yuan (RMB)/ton \\
\hline LH2201 & 28680yuan (RMB)/ton \\
\hline
\end{tabular}

As shown in Table 2, There are three contracts trading in the market, whose code is LH2109, LH2111 and LH2201 respectively[3]. They represent forward hog prices for September 2021, November 2021 and January 2022. The contract details of hogs futures are carefully designed.

\subsubsection{Trading Unit and Minimum Price Change}

Table 1 shows that the trading unit is limited to 16 tons/ board lots, which is the weight of about 135 live hogs. This is the transfer volume of a 9.6 meters high three-story truck. If the price of hogs is 30 thousand yuan/ton, then the overall value of one board lot is 480 thousand yuan. This design fits the need of live hog trading habit and is fit for enterprises to do hedging between periods.

The unit change of the contract determines the liquidation of the hog futures. If it is too small, the trading will not have efficiency. But a large change can lead to less quoted price. Still assume the price is 30 thousand yuan/ton, when a maximum deviation of $4 \%$ is reached, 5 yuan/ton in unit change leads to 240 changes.

\subsubsection{Delivery of the Hog Futures}

\section{- Ways of Delivery}

Delivery of hogs mainly have two modes, including standard warehouse receipt delivery and board delivery[3]. For the previous one, the Exchange guarantees for the hog quality with check before acceptance of hogs into specific warehouses a necessary process. Right after matching of seller and buyer, the standard receipt, which stands for ownership of hogs, transfers immediately from the seller to the buyer. And the margin for sales position is cleared immediately. However, board delivery has its feature when both sides share the risk by using whether the hog is on board as a way to decide responsibility of fault. For the seller, it is more convenient due to lessened procedures but they get the margin back six days after delivery is confirmed.

\subsection{Delivery Price}

Delivery price of hogs takes mainly three factors into consideration - the live hog price, premiums \& discounts and over $\&$ short of hog weights. Live hog price is related to a settlement price of the contract. Hogs weights delivered per batch over or short than 16 tons should pay extra fees. Premiums and discounts are most important when taking the quality of hogs and delivery places into account. The formula of price $=($ price of live hogs + non - standard warehouse premiums / discounts + quality premiums / discounts ) $\times$ over / short weight[3] .

Referring to Table 3, normally the contract requires the hogs' average weight to be among 100 to 120 kilogram, and the single weight must be among 90 to 140 kilograms. The pigs must have no obvious blemish in appearance. If pigs have lumps in the body surface or can not walk as normal, an extra 50 or 100 yuan / hog is required separately. Average weight should not be lower than 100 kilograms, but a 10 kilograms upward is allowed. After the average weight exceeds 130 kilograms, 600 yuan / ton should be paid by the seller. If it goes over 140, 100 yuan / ton is paid. Furthermore, the hog should neither be too fat or too weak. Overweight is charged 200 
yuan / hog and underweight is asked for more. This helps to control quality of the standard physical delivery.

Table 3. Premiums and Discounts in Delivery Price according to Hog Quality[3]

\begin{tabular}{|c|c|c|}
\hline Aspect & Conditions & $\begin{array}{c}\text { Premiums } \\
\text { and Discount }\end{array}$ \\
\hline \multirow{4}{*}{ Appearance } & $\begin{array}{c}\text { With a hernia or } \\
\text { can not walk } \\
\text { naturally }\end{array}$ & $\begin{array}{c}100 \text { yuan per } \\
\text { hog }\end{array}$ \\
\cline { 2 - 3 } & $\begin{array}{c}\text { With purulent } \\
\text { ules or lumps in } \\
\text { body surface }\end{array}$ & $\begin{array}{c}50 \text { yuan per } \\
\text { hog }\end{array}$ \\
\hline \multirow{3}{*}{$\begin{array}{c}\text { Average } \\
\text { Weight/ }(\text { Kg })\end{array}$} & $(120,130]$ & 0 yuan per ton \\
\cline { 2 - 3 } & $>140,140]$ & $\begin{array}{c}600 \text { yuan per } \\
\text { ton }\end{array}$ \\
\hline \multirow{2}{*}{$\begin{array}{c}\text { Single Weight/ } \\
\text { ( Kg })\end{array}$} & $(140,150]$ & $\begin{array}{c}1000 \text { yuan per } \\
\text { ton }\end{array}$ \\
\cline { 2 - 3 } & $>150$ & 200 yuan per hog hog \\
\cline { 2 - 3 } & $<90$ & 1000 per hog \\
\hline
\end{tabular}

Dalian Commodity Exchange has set Henan Province as a basic delivery position. It is located near the middle, separating pig breeding regions to south parts and north parts. Also it almost holds the biggest hog industry in China, with 26.89 million hog inventory in 2020. The famous pig raising company MuYuan is from Henan Province. Its price can best stand for the conditions of the hog industry.

In Figure 1, using Henan's hog delivery price as a reference, countries in the north are given cheaper delivery price for buyers. Inner Mongolia and Liaoning Province have discounts of $500-600$ yuan / ton. While with the location goes south-west and inland, high premiums in price are shown. Sichuan Province has premium of 1500 yuan / ton.

The reason for the Exchange to set such discounts and premiums is to balance the differences of price between regions, as seen in Figure 2. North of China enjoys a lower spot market price of live hogs than south of China. So if the delivery price is set as the same, then sellers from North will prefer to trade in the futures market and those from South will only trade expensive spot hogs. The imbalanced liquidation is not a result the Exchange wants to see. There can exist an arbitrage opportunity.

For example, the live hog price in Sichuan is 1500 yuan/ton higher than that in Henan. When sellers are allowed to deliver goods in the Henan's price, buyers from Henan will choose to receive delivery in Sichuan and sell them there to earn 1500 yuan/ton more than in Henan. On the opposite, if price in Inner Mongolia is 600 yuan lower, sellers buy pigs there to deliver. Then they sell their pigs in Henan to earn 600 yuan.

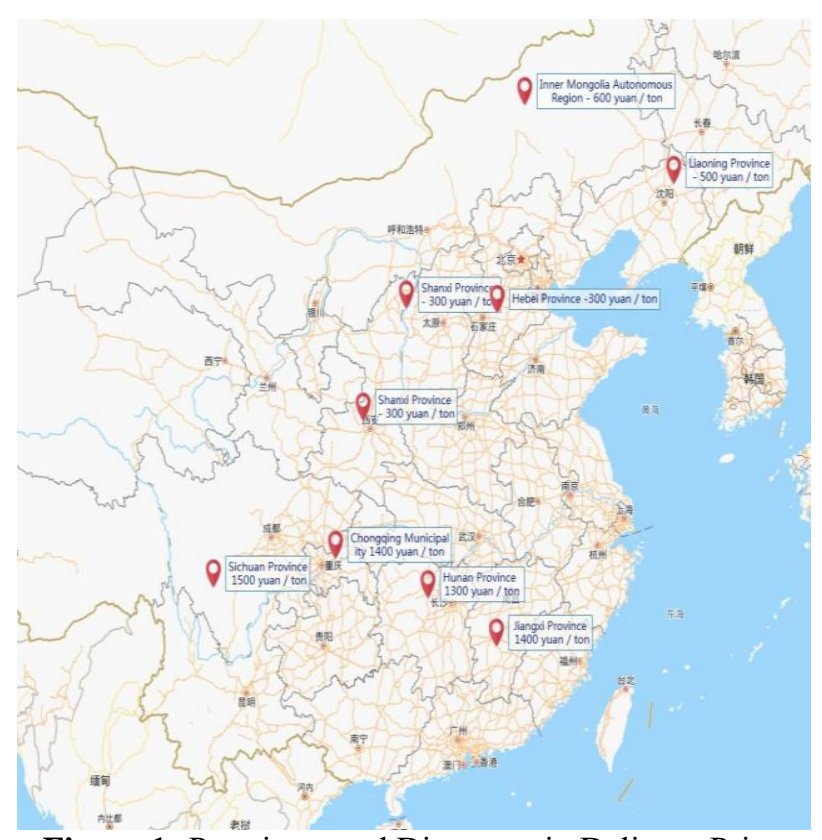

Figure 1 Premiums and Discounts in Delivery Price according to Location

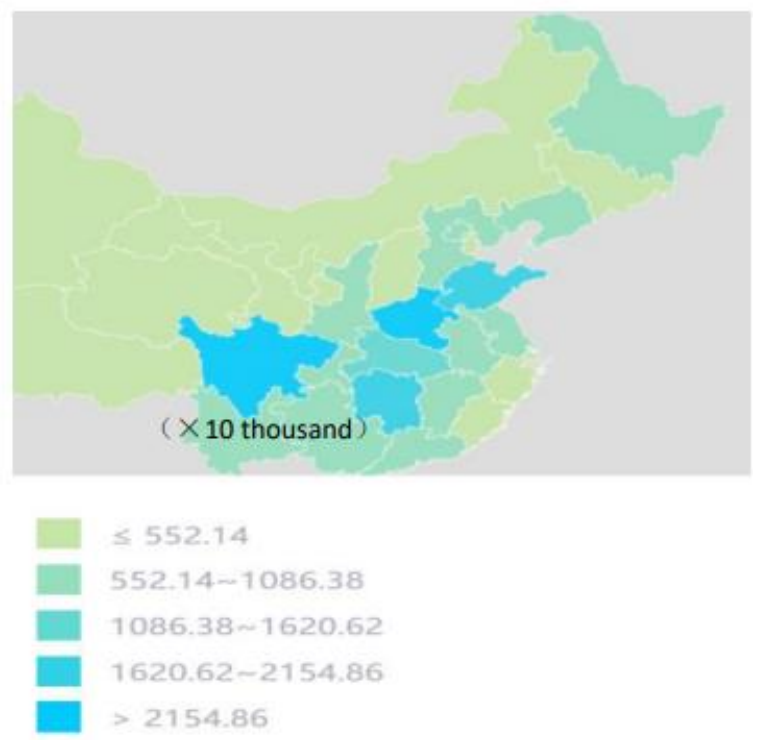

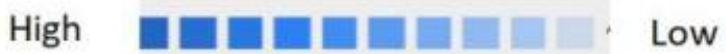




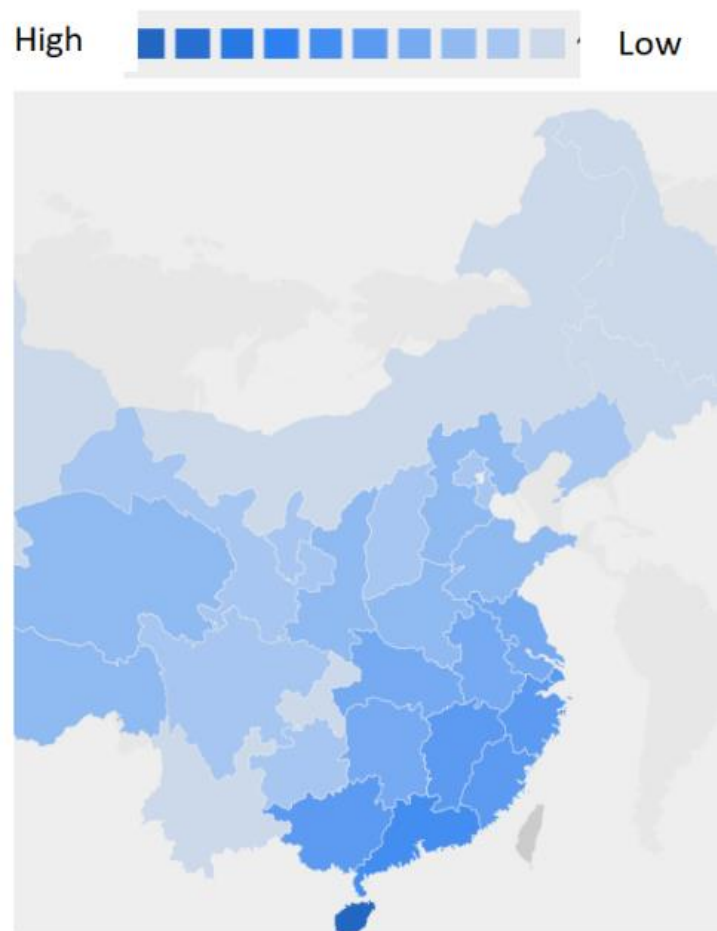

Figure 2 Supply (Left) and Price (Right) of Live Hogs in China[4]
The differences between prices have already explained the demand and supply relationship and transportation fees between regions. To encourage traders to deliver in their regions and to add liquidation to the futures market, the Exchange investigated carefully to set the discounts and premiums.

\subsubsection{Risk Management}

Table 4. Position Limits of Traders in the Hog Futures[3]

\begin{tabular}{|c|c|c|c|}
\hline Contract Month & Trading Period & Non - members & Clients \\
\hline \multirow{4}{*}{$\begin{array}{l}\text { Non July } \\
\text { Contracts }\end{array}$} & From the issue of contract & 500 & 500 \\
\hline & $\begin{array}{c}\text { From the 1st trading day of the month before the } \\
\text { delivery month }\end{array}$ & 125 & 125 \\
\hline & $\begin{array}{l}\text { From the 10th trading day of the month before } \\
\text { the delivery month }\end{array}$ & 30 & 30 \\
\hline & Delivery month & 10 & 10 \\
\hline \multirow{4}{*}{ July Contracts } & From the Issue of contract & 200 & 200 \\
\hline & $\begin{array}{c}\text { From the 1st trading day of the month before the } \\
\text { delivery month }\end{array}$ & 50 & 50 \\
\hline & $\begin{array}{l}\text { From the 10th trading day of the month before } \\
\text { the delivery month }\end{array}$ & 10 & 10 \\
\hline & Delivery month & 5 & 5 \\
\hline
\end{tabular}

Table 4 illustrates how the hog futures set limits to traders' position. Basically, traders are allowed to hold at most 500 board lots before the previous month of the delivery month. The requirement goes to 10 board lots in the delivery month. Contracts in July has a more strict limit in the position when July witnesses pigs' stress response to high temperature in summer. The south of China is also prone to the rainstorm and floods, which affects smooth delivery. This limit will not be a problem for majority of market participants like slaughter houses and individual farmers. In 2020, the number of hogs that are fully grown for sale reaches 0.527 billion, which is 43.92 million per month. Assume the average weight of one hog is 110 kilograms, then the whole month's hog supply can reach 300 thousand board lots. Even if individual farmers are not likely to sell, buyers can regain position after finishing delivery or sale.

\subsection{Typical Methods of Hedging with Live Hog Futures}

The position of the hog raising enterprises in the supply chain determines that it is destined to be squeezed by the upstream and downstream. They are easy to be exposed to raw material cost fluctuation and competitions from selling hogs in the market.

The cost of pig breeding is mainly from piglets, feed, labor, equipment depreciation, health care and water and electricity cost. And feed is mainly composed of corns and soybeans, which has been listed in the futures market. 
Therefore, hog breeding enterprises can form an strategy combing crop futures and live hog futures[5].

For example, when the pork price is high but prices of corns and soybeans are in a lower level, the breeding enterprises worry about a rise in cost caused by raw materials. At the same time, demand in pigs decreases when pork price shrinks. So they buy corns and soybeans futures while be in a short position to sell hog contracts. After the price of crops rises and that of hogs decreases as they predict, they short crop futures and long hog futures to avoid risk.

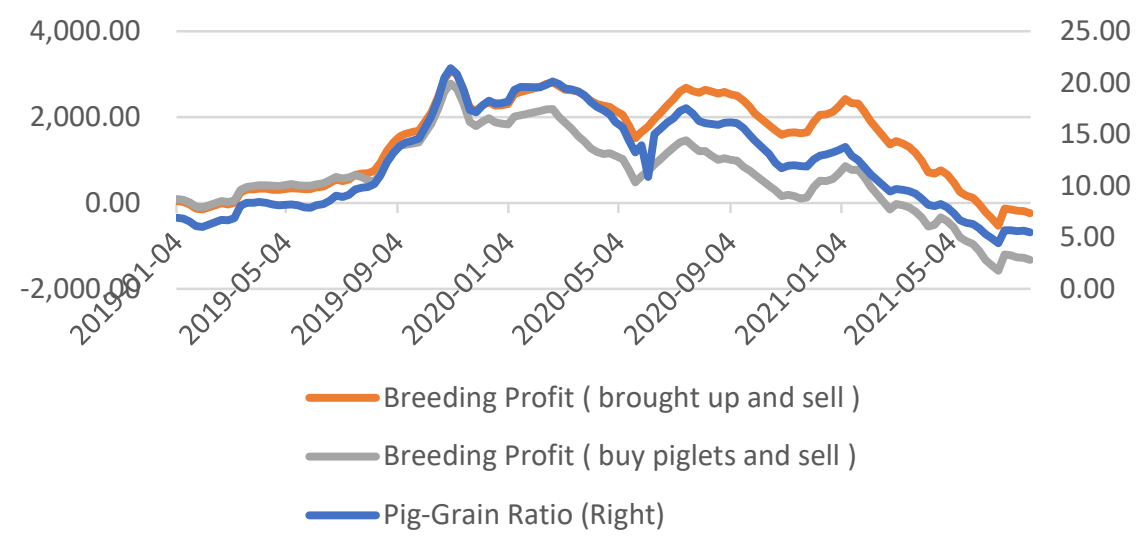

Figure 3 Pig-Grain Ratio and Breeding Profit of Hogs

To be specific, like in Figure 3, the company can take advantage of the period before May, 2020 to long crop futures and short live hog futures (suppose it is issued then). This is the time when hog price / crop price is rising and breeding profit is high. When the trend turns inversely, they can earn and reduce loss from double shock of rising material cost and decreasing hog value.

\subsection{Major Benefits of Hog Futures to the Supply Chain of Hog Industry}

\subsubsection{Promotion of Farming, Processing, and Distribution}

The implementation of hog futures provides an accurate and effective price reference for the participants of the whole supply chain of pork.

Generally speaking, the pork supply chain is divided into upstream feed supply (including soybean meal and corn), piglet supply, veterinary drugs, and vaccines supply, the prices of which basically represent the cost of raising pigs. In the middle of the supply chain are pig farms. Further down the pork supply chain are hog traders, slaughterhouses, transportation, wholesale markets, and packinghouse. The profits of participants in the pork supply chain, especially those in the middle and downstream of the supply chain, are heavily affected by the price fluctuations of the pig cycle. However, the cyclical fluctuations of China's pig production and pork prices are related to the lack of futures prices that can effectively reflect the supply and demand in the future.

After hog futures came into the market, a reference of the hog prices for the next six months was provided for the whole market, which is a comprehensive embodiment of the supply, demands, and hog prices in the future from almost all the market participants' expectations Compared with the previous situation in China that various mathematical models and historical data could only predict hog prices in the future, the issue of hog futures is a milestone of the development in the Chinese hog market.

For downstream, participants in the pork supply chain, such as distributors, can manage the risk of price fluctuations in procurement and sales by participating in the pig futures market. Slaughtering plant enterprises and pork traders can also use hog futures to lock in the procurement cost at an ideal level. In this way, participants involved in the whole hog industry can use futures to avoid price risk. Thus, the fluctuation of pork prices is stabilized from the supply.

\subsubsection{Smooth the Pig Cycle}

Companies and individuals can use the future to hedge the hog price cycle. The hog price cycle is a phenomenon that is affected by many different factors. Usually, the hog price cycle is related to the price of the pork and the price of fodder. When the pork is expensive, the farmers, especially the individual farmers, tend to raise the amount of livestock on hand, which costs the number of piggies and female pigs to rise tremendously. However, the price of pork has a strong relationship with the output of pigs. When the piggy that has been stock by the farmer during the high price period becomes large enough to sell, the price has already dropped. During the low-price period, farmers who invest in piggy and female pigs will face losses. The losses will push many small farms out of the market. As the number of farm decrease, there will be a surplus and the surplus will cost the price rise again. 2020 can be a great example of a short cycle 
at the end of 2020, the pork price rises tremendously, which cost $29.2 \%$ rise on the number of livestock on hand as a result, in spring 2021, the output of pigs rise $34.4 \%$, and cost the price of pork drop from more than 40 yuan to only a little bit over 20 yuan[6]. However, as the hog future entrée the market, the farmers can predict the future price from the futures contract. In this case, companies and individual farms can use the future price to control the number of livestock on hand. According to the experience from America, after the future issue, the price cycle becomes more and more stable. The companies have a chance to use the future as a risk management tool to analyze future price and use it to hedge the cycle to maintain stable income during the price cycle. It is clear from Figure 4 that the US hog price did not change as much as the Chinese pork price. Even though the cycle is still happening in the US, the companies have used futures to judge the market direction skillfully[6].

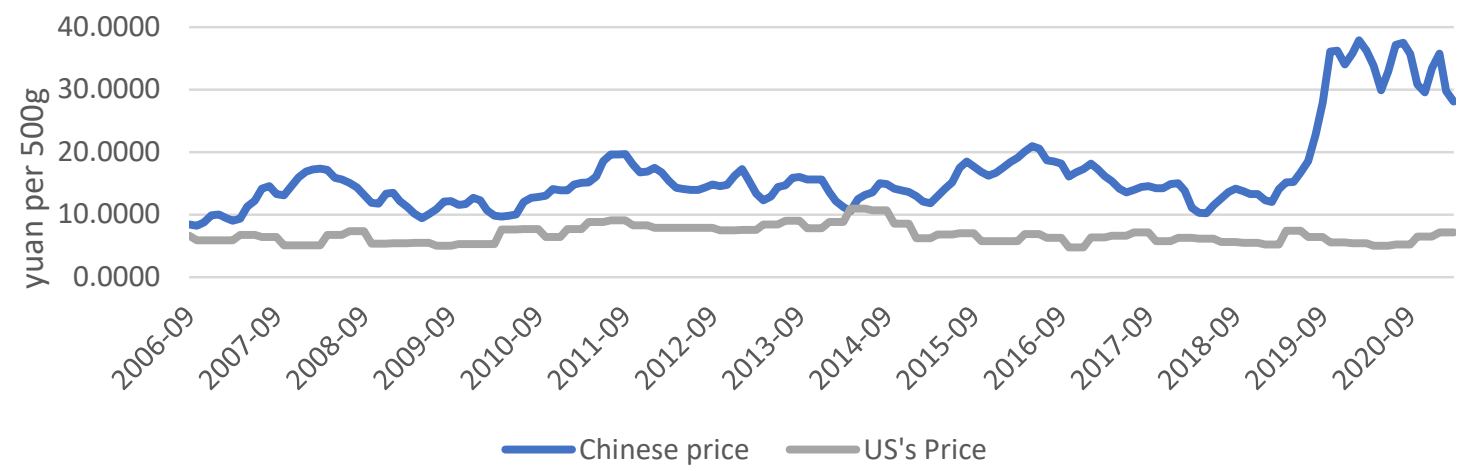

Figure 4 The Pork Price between the US and China

\subsubsection{Help the Government Control Future Pork Prices}

Government plays a vital role in the Chinese agriculture market. Pork is the primarily purchased meat in China based on the China statistical yearbook of 2019. In 2013, residents' per capita pork consumption was about $77.34 \%(19.8 \mathrm{KG})$, and the amount of pork consume is rising continuously. In 2018 the per capita pork consumption rises from $25.6 \mathrm{KG}$ to $29.5 \mathrm{KG}$. Since pork plays an essential role in the Chinese agriculture market, the government consistently awards pork. In 2020 the pork price went over 50 yuan per $500 \mathrm{~g}$. The government starts to put in the frozen pork from the national treasury to decrease the pork price. In 2020, there are more than 670,000 tons of pork put into the market[6].

However, the government reacts to the low pork price and buys pork to fill the state treasury, and this action can raise the pork price to protect farmers and companies. However, because the demand for pork is exceptionally high, the government cannot control the price. In this case, the future is beneficial because the government can analyze and predict the future market based on the future. Future would help the relative governmental department act ahead of time to reduce costs and make the action more efficient.

\section{EMPIRICAL ANALYSIS OF INFLUENCE OF THE HOG FUTURES}

The paper aims to conduct an empirical analysis on the interactions between major products of the live hog supply chain analyzed above. Referring to Liang, Liu and
Yang, we consider factors like feed price, live hog price and pork price. Afterwards, the paper assumes that the relationship will not change much and uses it as a basis to predict the price of live hogs without issuing the hog futures. Previously, prediction is much done by single time-series analysis with advanced machine learning methods, like Liu et al.[7]. But it has less economic meaning and is not that effective after important events like COVID-19 outbreak. This paper improves it with results from perspective of the supply chain.

In American, the issue of hog futures were proved to be effective by Carter and Mohapatra[9]. Whether it works well in China is in the center of discussion in this part.

\subsection{Data Source and Sample Selection}

Data used in the paper are time series of average prices in weekly frequency, ranging from July, 2006 to July, 2021. The prices are all from major products along the hog industry supply chain, which includes soybeans, corns, piglets, live hogs and pork. Removing all samples with null values, we finally get a valid series of 738 observations. All data are collected from Wind macroeconomic database.

Later we are going to model price interactions before the issue of hog futures. Data range is limited from $7^{\text {th }}$ July, 2006 to $1^{\text {st }}$ Jan, 2021, which is right before the coming out of hog futures. Assuming such relationship between products will not change drastically in a shortterm, we predict price of hogs using estimated parameters to simulate the possible live hog price in the condition when the future is not issued. This allows comparison 
between supposed conditions and real ones. Data in the prediction model is from $8^{\text {th }}$ Jan, 2021 to $23^{\text {th }}$ July, 2021.

\subsection{Variable Definition}

Variables considered are prices of the most representative products along the hog supply chain. They are classified by the role they take and listed as follows.

- Cost Before Sale

Price of soybeans and corns (Soybean, Corn): The most essential factor to be considered by farmers when choosing the number of pigs to raise.

Price of piglets: Feeders who lack physical conditions to propagate and raise hogs themselves would choose to buy small hogs to bring them up.

- Earning From Sale

Price of live hogs (LH) : When the pigs are around 110 kilograms, they are defined as fully grown and ready for slaughter. If they continue to grow, then the marginal cost of feeding them is going to increase. Therefore, the farmers will catch the chance to sell.

- Price Paid by Consumers

Price of Pork (Pork) : After hogs are slaughtered, they are processed into pork to sell to the market.

\subsection{Vector Auto Regression Model Building}

With information criteria, the model is proper to be set in a form with lag 4 or more. Because prices influence each other across time periods, so Vector Auto Regression (VAR) is the best fit. After fitting the model with historical data, we find that when lag period is 5, there will be no serial correlation of residuals. This meets the assumption of VAR model and is intuitive when prices a month (4-5 weeks) ago have strong predictive power.

Model to construct relationships between prices of soybeans, corns, piglets, live hogs and pork could be expressed as follows:

$$
\left(\begin{array}{l}
\mathrm{LH}_{t} \\
\mathrm{SH}_{t} \\
\text { Pork }_{t} \\
\text { Corn }_{t} \\
\text { Soybean }_{t}
\end{array}\right)=\mathrm{B}_{0}+\mathrm{B}_{1}\left(\begin{array}{l}
\mathrm{LH}_{t-1} \\
\mathrm{SH}_{t-1} \\
\text { Pork }_{t-1} \\
\text { Corn }_{t-1} \\
\text { Soybean }_{t-1}
\end{array}\right)+\mathrm{B}_{2}\left(\begin{array}{l}
\mathrm{LH}_{t-2} \\
\mathrm{SH}_{t-2} \\
\text { Pork }_{t-2} \\
\text { Corn }_{t-2} \\
\text { Soybean }_{t-2}
\end{array}\right)+\mathrm{B}_{3}\left(\begin{array}{l}
\mathrm{LH}_{t-3} \\
\mathrm{SH}_{t-3} \\
\text { Pork }_{t-3} \\
\text { Corn }_{t-3} \\
\text { Soybean }_{t-3}
\end{array}\right)+\mathrm{B}_{4}\left(\begin{array}{l}
\mathrm{LH}_{t-4} \\
\mathrm{SH}_{t-4} \\
\text { Pork }_{t-4} \\
\text { Corn }_{t-4} \\
\text { Soybean }_{t-4}
\end{array}\right)+\mathrm{B}_{5}\left(\begin{array}{l}
\mathrm{LH}_{t-5} \\
\mathrm{SH}_{t-5} \\
\text { Pork }_{t-5} \\
\text { Corn }_{t-5} \\
\text { Soybean }_{t-5}
\end{array}\right)+\mathrm{U}_{\mathrm{t}}
$$

$\mathrm{B}_{1}, \mathrm{~B}_{2}, \mathrm{~B}_{3}, \mathrm{~B}_{4}, \mathrm{~B}_{5}$ are all $(5 \times 5)$ matrices with 25

have showed strong relationship. Table 5 describes some statistical evidence. The volatility of piglet price is much higher. Except for price of feeds, the live hog price has the lowest mean value.

\subsection{Result Analysis}

\subsubsection{Descriptive Statistics}

Figure 5 shows the historical price change of the five target products. They almost change simultaneously and

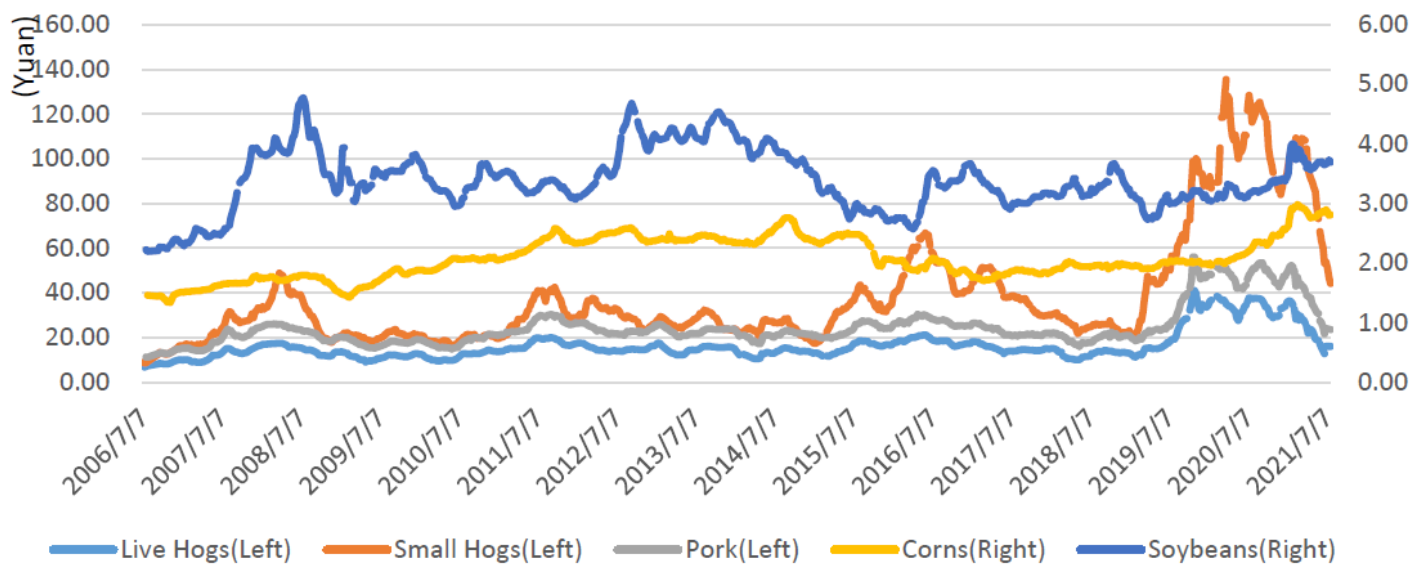

Figure 5 Prices of Major Products Along the Supply Chain 
Table 5. Descriptive Data

\begin{tabular}{cccccc}
\hline Variable & Obs & Mean & Std.Dev. & Min & Max \\
\hline LH & 742 & 16.40 & 6.61 & 6.76 & 40.98 \\
SH & 743 & 38.67 & 25.76 & 8.60 & 135.47 \\
Pork & 741 & 24.70 & 8.84 & 11.14 & 56.02 \\
Corn & 739 & 2.09 & 0.35 & 1.34 & 2.98 \\
Soybean & 738 & 3.39 & 0.49 & 2.19 & 4.77 \\
\hline
\end{tabular}

3.4.2 Price Interactions of Major Products Along the Supply Chain

Table 6. VAR Model Parameter Estimation

\begin{tabular}{|c|c|c|c|}
\hline Dependent Variable & Excluded & F Statistic & P Value \\
\hline \multirow{5}{*}{ LH } & $\mathrm{SH}^{\star \star *}$ & 5.8171 & 0.0000 \\
\hline & Pork** & 3.9926 & 0.0014 \\
\hline & Corn* & 2.7978 & 0.0164 \\
\hline & Soybean & 1.0361 & 0.3953 \\
\hline & $A L L^{* * *}$ & 3.6450 & 0.0000 \\
\hline \multirow{5}{*}{$\mathrm{SH}$} & $\mathrm{LH}^{* * *}$ & 13.3970 & 0.0000 \\
\hline & Pork ${ }^{* * *}$ & 5.7504 & 0.0000 \\
\hline & Corn & 1.4019 & 0.2215 \\
\hline & Soybean & 1.5629 & 0.1684 \\
\hline & $A L L^{* * *}$ & 5.6900 & 0.0000 \\
\hline \multirow{5}{*}{ Pork } & $\mathrm{LH}^{* * *}$ & 63.6070 & 0.0000 \\
\hline & $\mathrm{SH}^{* \star *}$ & 8.9653 & 0.0000 \\
\hline & Corn** & 3.4001 & 0.0048 \\
\hline & Soybean & 0.2725 & 0.9282 \\
\hline & $A L L^{* * *}$ & 21.9400 & 0.0000 \\
\hline \multirow{5}{*}{ Corn } & $\mathrm{LH}$ & 2.1691 & 0.0559 \\
\hline & $\mathrm{SH}^{\star *}$ & 3.7674 & 0.0023 \\
\hline & Pork ${ }^{*}$ & 2.4232 & 0.0343 \\
\hline & Soybean & 2.2174 & 0.0510 \\
\hline & $A L L^{* * *}$ & 2.3911 & 0.0006 \\
\hline \multirow{5}{*}{ Soybean } & LH & 0.3892 & 0.8564 \\
\hline & $\mathrm{SH}$ & 0.6188 & 0.6855 \\
\hline & Pork & 0.5057 & 0.7721 \\
\hline & Corn & 0.6554 & 0.6575 \\
\hline & ALL & 0.4861 & 0.9719 \\
\hline
\end{tabular}

$t$ statistics in parentheses

${ }^{*} p<0.05,{ }^{* *} p<0.01,{ }^{* * *} p<0.001$

Table 7. Granger - Causality Test Outcome

\begin{tabular}{|c|c|c|c|c|c|}
\hline & (1) & (2) & (3) & (4) & (5) \\
\hline $\begin{array}{l}\text { Independ } \\
\text { ent Var }\end{array}$ & LH & $\mathrm{SH}$ & Pork & Corn & Soybean \\
\hline \multicolumn{6}{|c|}{ LH } \\
\hline L1 & $\begin{array}{c}1.529^{\star \star \star} \\
(32.15)\end{array}$ & $\begin{array}{c}0.0327^{* *} \\
(3.05)\end{array}$ & $\begin{array}{c}-0.0152 \\
(-0.39)\end{array}$ & $\begin{array}{l}-0.854 \\
(-0.97)\end{array}$ & $\begin{array}{l}-0.292 \\
(-0.85)\end{array}$ \\
\hline L2 & $\begin{array}{c}-0.445^{\star * \star} \\
(-5.90)\end{array}$ & $\begin{array}{c}-0.0644^{* * *} \\
(-4.05)\end{array}$ & $\begin{array}{c}-0.0939^{*} \\
(-2.03)\end{array}$ & $\begin{array}{c}3.613^{\star *} \\
(2.81)\end{array}$ & $\begin{array}{l}0.350 \\
(0.56)\end{array}$ \\
\hline
\end{tabular}




\begin{tabular}{|c|c|c|c|c|c|}
\hline L3 & $\begin{array}{l}-0.0964 \\
(-1.26)\end{array}$ & $\begin{array}{c}0.0604^{\star \star \star} \\
(3.71)\end{array}$ & $\begin{array}{l}-0.0569 \\
(-1.24)\end{array}$ & $\begin{array}{c}-3.592^{\star *} \\
(-2.79)\end{array}$ & $\begin{array}{l}-0.130 \\
(-0.20)\end{array}$ \\
\hline L4 & $\begin{array}{c}0.308^{\star \star *} \\
(4.09)\end{array}$ & $\begin{array}{c}-0.0618^{\star \star \star} \\
(-3.76)\end{array}$ & $\begin{array}{c}0.00789 \\
(0.17)\end{array}$ & $\begin{array}{l}0.611 \\
(0.47)\end{array}$ & $\begin{array}{c}-0.0697 \\
(-0.11)\end{array}$ \\
\hline L5 & $\begin{array}{c}-0.227^{\star \star \star} \\
(-4.19) \\
\end{array}$ & $\begin{array}{c}0.0348^{* *} \\
(3.22) \\
\end{array}$ & $\begin{array}{c}0.0994^{\star *} \\
(2.79)\end{array}$ & $\begin{array}{l}0.351 \\
(0.40) \\
\end{array}$ & $\begin{array}{c}0.0482 \\
(0.14) \\
\end{array}$ \\
\hline \multicolumn{6}{|c|}{ SH } \\
\hline L1 & $\begin{array}{c}1.198^{\star \star *} \\
(6.71)\end{array}$ & $\begin{array}{l}1.131^{* * *} \\
(28.06)\end{array}$ & $\begin{array}{c}-0.655^{\star \star \star} \\
(-4.47)\end{array}$ & $\begin{array}{l}2.305 \\
(0.70)\end{array}$ & $\begin{array}{l}-0.341 \\
(-0.26)\end{array}$ \\
\hline L2 & $\begin{array}{l}-0.567^{*} \\
(-2.00)\end{array}$ & $\begin{array}{l}-0.135^{\star} \\
(-2.27)\end{array}$ & $\begin{array}{l}0.395^{\star} \\
(2.27)\end{array}$ & $\begin{array}{l}5.268 \\
(1.09)\end{array}$ & $\begin{array}{l}-1.055 \\
(-0.45)\end{array}$ \\
\hline L3 & $\begin{array}{c}0.0540 \\
(0.19)\end{array}$ & $\begin{array}{c}0.0850 \\
(1.39)\end{array}$ & $\begin{array}{l}-0.308 \\
(-1.79)\end{array}$ & $\begin{array}{l}-7.316 \\
(-1.51)\end{array}$ & $\begin{array}{l}0.643 \\
(0.26)\end{array}$ \\
\hline L4 & $\begin{array}{l}0.228 \\
(0.81)\end{array}$ & $\begin{array}{c}-0.194^{\star *} \\
(-3.14)\end{array}$ & $\begin{array}{c}0.0727 \\
(0.42)\end{array}$ & $\begin{array}{l}-2.633 \\
(-0.54)\end{array}$ & $\begin{array}{l}0.566 \\
(0.24)\end{array}$ \\
\hline L5 & $\begin{array}{l}-0.344 \\
(-1.69) \\
\end{array}$ & $\begin{array}{c}0.0514 \\
(1.27)\end{array}$ & $\begin{array}{l}0.241 \\
(1.80) \\
\end{array}$ & $\begin{array}{l}2.190 \\
(0.67) \\
\end{array}$ & $\begin{array}{l}-0.209 \\
(-0.16)\end{array}$ \\
\hline \multicolumn{6}{|c|}{ Pork } \\
\hline L1 & $\begin{array}{l}0.844^{* * *} \\
(14.76)\end{array}$ & $\begin{array}{c}0.0552^{\star \star \star} \\
(4.28)\end{array}$ & $\begin{array}{c}0.586^{\star * *} \\
(12.46)\end{array}$ & $\begin{array}{l}0.487 \\
(0.46)\end{array}$ & $\begin{array}{l}0.270 \\
(0.65)\end{array}$ \\
\hline L2 & $\begin{array}{l}-0.286^{\star *} \\
(-3.16)\end{array}$ & $\begin{array}{c}-0.107^{\star \star *} \\
(-5.59)\end{array}$ & $\begin{array}{c}0.0385 \\
(0.69)\end{array}$ & $\begin{array}{l}1.987 \\
(1.29)\end{array}$ & $\begin{array}{l}-0.205 \\
(-0.27)\end{array}$ \\
\hline L3 & $\begin{array}{c}-0.364^{\star * \star} \\
(-3.96)\end{array}$ & $\begin{array}{c}0.0971^{* * *} \\
(4.96)\end{array}$ & $\begin{array}{l}0.146^{\star *} \\
(2.65)\end{array}$ & $\begin{array}{l}-2.731 \\
(-1.76)\end{array}$ & $\begin{array}{l}-0.369 \\
(-0.47)\end{array}$ \\
\hline L4 & $\begin{array}{l}0.213^{*} \\
(2.36)\end{array}$ & $\begin{array}{c}-0.0760^{\star * *} \\
(-3.84)\end{array}$ & $\begin{array}{l}-0.0503 \\
(-0.91)\end{array}$ & $\begin{array}{l}-1.452 \\
(-0.93)\end{array}$ & $\begin{array}{l}0.287 \\
(0.38)\end{array}$ \\
\hline L5 & $\begin{array}{c}-0.0195 \\
(-0.30)\end{array}$ & $\begin{array}{c}0.0293^{*} \\
(2.26)\end{array}$ & $\begin{array}{c}-0.00971 \\
(-0.23)\end{array}$ & $\begin{array}{l}1.999 \\
(1.90)\end{array}$ & $\begin{array}{c}-0.0134 \\
(-0.03)\end{array}$ \\
\hline \multicolumn{6}{|c|}{ Corn } \\
\hline L1 & $\begin{array}{c}0.000165 \\
(0.08)\end{array}$ & $\begin{array}{c}-0.00107^{*} \\
(-2.30)\end{array}$ & $\begin{array}{c}0.00352^{*} \\
(2.08)\end{array}$ & $\begin{array}{l}1.087^{\star \star \star} \\
(28.61)\end{array}$ & $\begin{array}{c}0.0349^{*} \\
(2.35)\end{array}$ \\
\hline L2 & $\begin{array}{c}-0.00248 \\
(-0.76)\end{array}$ & $\begin{array}{l}0.000463 \\
(0.67)\end{array}$ & $\begin{array}{c}-0.00253 \\
(-1.27)\end{array}$ & $\begin{array}{c}0.184^{\star \star \star} \\
(3.33)\end{array}$ & $\begin{array}{c}-0.0300 \\
(-1.12)\end{array}$ \\
\hline L3 & $\begin{array}{c}0.00771^{*} \\
(2.34)\end{array}$ & $\begin{array}{c}0.00159^{*} \\
(2.27)\end{array}$ & $\begin{array}{c}-0.00405^{*} \\
(-2.04)\end{array}$ & $\begin{array}{c}-0.0942 \\
(-1.70)\end{array}$ & $\begin{array}{c}-0.0410 \\
(-1.47)\end{array}$ \\
\hline L4 & $\begin{array}{c}-0.00878^{* *} \\
(-2.71)\end{array}$ & $\begin{array}{c}0.000162 \\
(0.23)\end{array}$ & $\begin{array}{c}0.00392^{*} \\
(1.97)\end{array}$ & $\begin{array}{c}-0.239^{\star * *} \\
(-4.29)\end{array}$ & $\begin{array}{l}0.0404 \\
(1.50)\end{array}$ \\
\hline L5 & $\begin{array}{c}0.00140 \\
(0.60)\end{array}$ & $\begin{array}{c}-0.000998^{*} \\
(-2.14)\end{array}$ & $\begin{array}{c}0.000325 \\
(0.21)\end{array}$ & $\begin{array}{c}0.0571 \\
(1.52)\end{array}$ & $\begin{array}{c}-0.00329 \\
(-0.22)\end{array}$ \\
\hline \multicolumn{6}{|c|}{ Soybean } \\
\hline L1 & $\begin{array}{c}0.00459 \\
(0.87)\end{array}$ & $\begin{array}{c}-0.000124 \\
(-0.10)\end{array}$ & $\begin{array}{c}-0.00300 \\
(-0.69)\end{array}$ & $\begin{array}{c}-0.0781 \\
(-0.80)\end{array}$ & $\begin{array}{l}1.507^{\star * *} \\
(39.34)\end{array}$ \\
\hline
\end{tabular}


L2

L5

$$
-0.00412
$$

$$
0.00414
$$

$-0.00931$

$$
0.00511
$$

$t$ statistics in parentheses

$$
{ }^{*} p<0.05,{ }^{* *} p<0.01,{ }^{* * *} p<0.001
$$

Drawing conclusions from the VAR model, we test the existence and direction of interactions between prices using Granger - Causality Test. The direction in Figure 6 is given by the most recent significant lagged coefficient of a product price on the other.

From Table 6 and Table 7, we can see that the price of soybeans is relatively independent from other prices of the products in hog industry. It does not change together with other four prices in every time lag, and the only price it will merely have one-period effect on the corn price positively.

$\begin{array}{ccc}0.00531 & 0.212 & -0.531^{\star * \star} \\ (1.03) & (1.48) & (-7.67) \\ & & \\ -0.00630 & -0.0930 & -0.0454 \\ (-1.23) & (-0.65) & (-0.63) \\ & & \\ 0.00587 & -0.0324 & 0.117 \\ (1.15) & (-0.22) & (1.69) \\ & & \\ -0.00255 & -0.00135 & -0.0604 \\ (-0.64) & (-0.01) & (-1.56)\end{array}$

The corn price has stronger relevance with the hog products price system. Its direct impact is imposed on the live hog price due to its importance as a primary feed. It takes 2-3 weeks to take effect. Inversely, the price of piglets, live hogs and pork also changes with corn price, which shows a power of crop sell's estimation to the future. The piglet and pork price are more recent. Rise in pork and hog price shows a promising demand in crops but rise in piglet prices discourages farmers from buying and raising pigs. The price of crops will decrease due to a shrinking market.

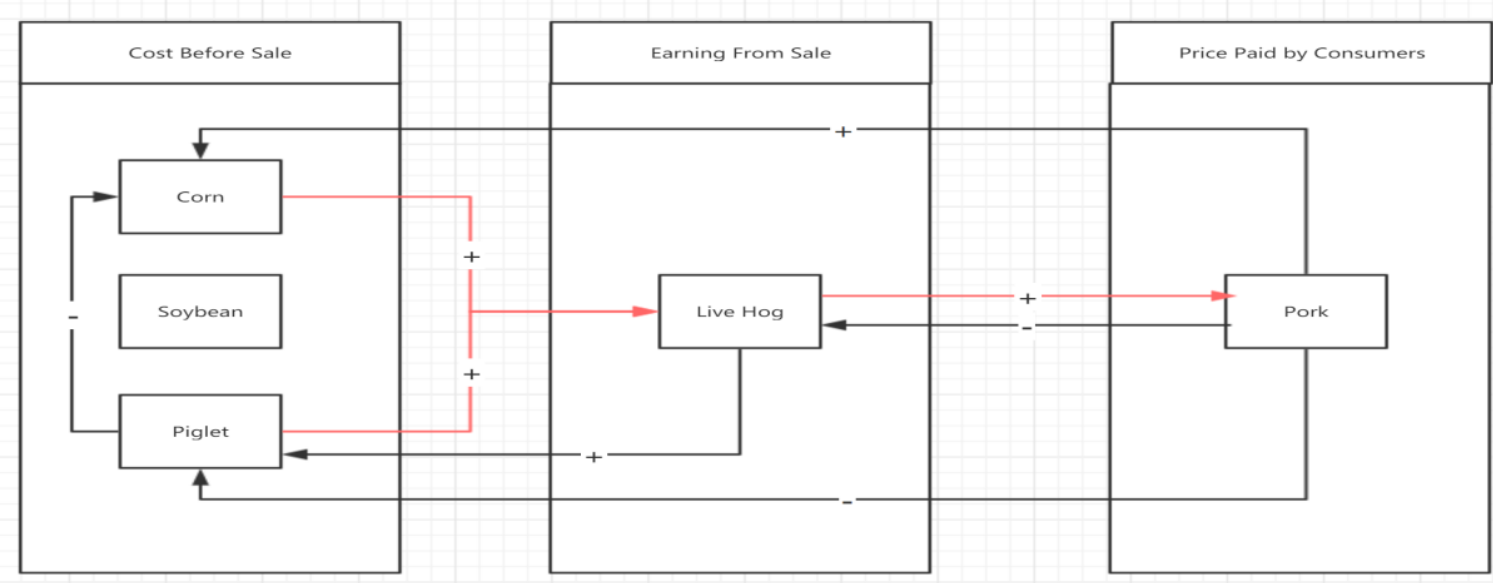

Figure 6 Causality Relationship between Prices

The price of piglets, live hogs and pork are even more significantly and closely correlated with each other. In most recent lag, the cost of piglets boosts hog price while pork price rise reduces it when feeders allow more fattening pigs to come into market, seizing the chance of a higher end sale price. Similarly, when feeders decide to raise more hogs, piglets are popular in market with higher price. Price of pork rises together drastically with both hog and piglet prices.

\subsubsection{Changes after the Issue of the Hog Futures}

Use the VAR model and parameters estimated above to predict prices after 8th Jan, 2021. The prediction is under the assumption that relationship between prices of corns, soybeans, piglets, live hogs and pork will not change much after the issue of the hog futures. Every time only one price is predicted. Other four prices are using real data after the issue of hog futures. Figure 7 tells that the model fits well in discovering a decreasing trend in prices generally. But the hog price shows an anomaly with its actual price dropping to a far lower extent when the prediction undergoes a recovery from decreasing.

The hog futures are still not functioning well now. The price of live hogs still plummets and not changes smoothly as the government and people wishes. The downward trend is first brought by a too sharply decrease in piglet prices. Four months later, the hog price begins to react. 

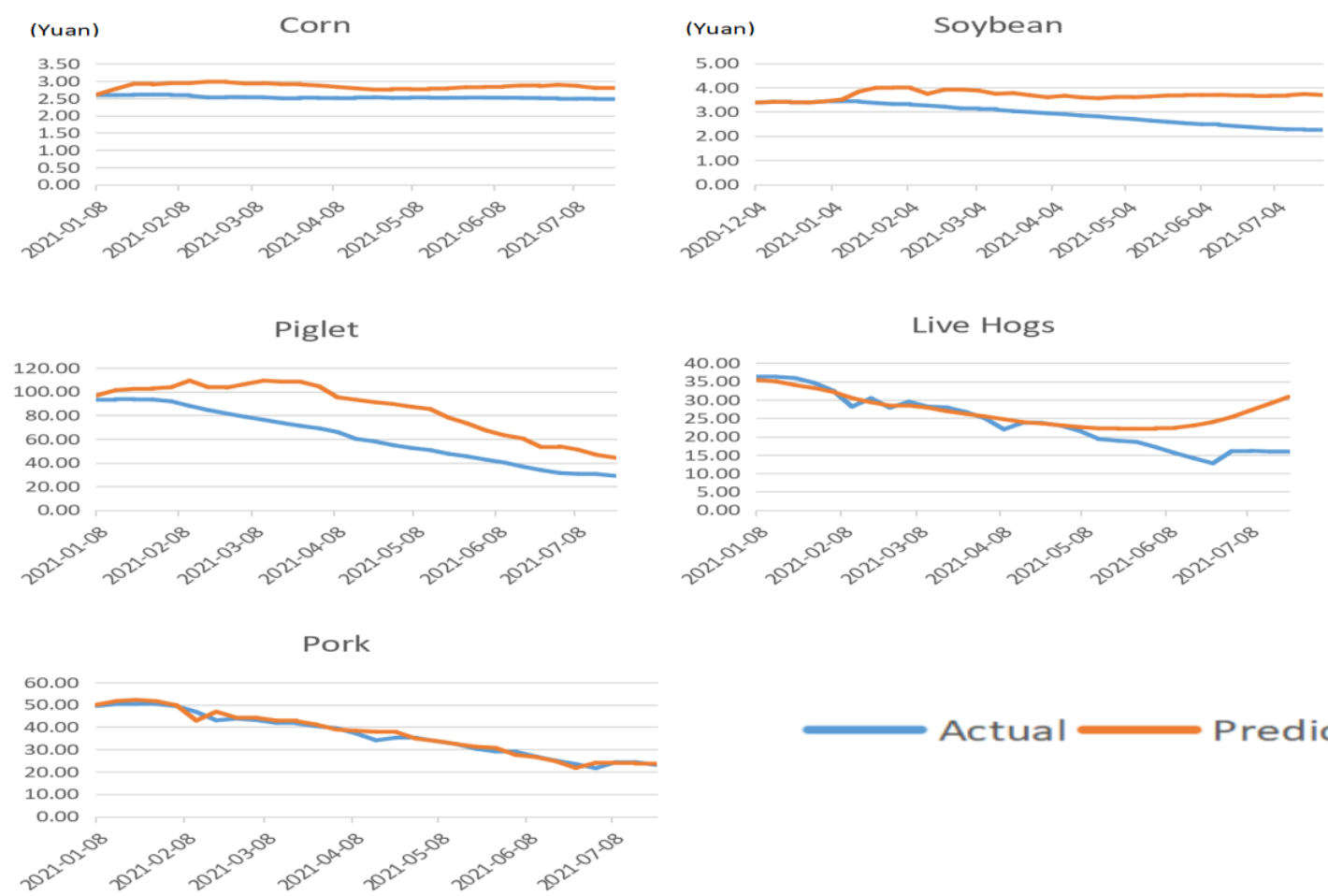

Figure 7 Actual Prices and Prediction After Issue of Hog Futures

\section{PROSPECT OF THE HOG FUTURES}

\subsection{Reasons for the Inefficiency of Hog Futures in China Market}

\subsubsection{The Structural Problem of Chinese Farmers}

From above analysis, the price of piglets and live hogs interacts with each other in a downward-sloping period. Even if the price of piglets keeps going down for months, it does not exhibit any hints for recovery. Buyers of piglets doesn't catch the chance to buy and raise more piglets when they are afraid of the price of live hogs remains unpromising. The hog futures do not convince feeders an effective protection from loss. The problem lies in the structure of farmers raising pigs in China.

Unlike the large-scale pig farming in the United States, the majority of Pig farmers in China are scattered small farmers or farms. In 2018, there were 37.75 million pig farmers (including enterprises) in China, of which 36.93 million were farmers with an annual output of less than 100 pigs, accounting for 97.83 percent of the total[10]. Since the delivery quantity required for each hand of hog futures is 16 tons, and the weight of pigs required for delivery is $100 \mathrm{~kg}$ to $120 \mathrm{~kg}$, the huge delivery number and strict delivery conditions of hog futures make most Chinese farmers unable to participate in the hog futures market for hedging. Therefore, especially when the situation is not good, they can not find a proper way to prevent loss.
So the price of piglets continues to go down. When the demand of live hogs rebounds, there will not be enough mature hogs if piglets are not in large demand now. The price of live hogs goes up again and encourages small farmers to buy more piglets. Again the mismatch of supply and demand exists.

This gives the spread of pig futures in China an obvious challenge.

\subsubsection{Big Enterprises Hesitate to Participate}

Before the listing of pig futures, many head pig enterprises have actively planned to participate in the relevant work of live pig futures. MuYuan, Wen Shares, Tianbang all claimed that futures professionals have been equipped.

However, about six months after the listing of pig futures, the head pig companies failed to get many 'benefits' from it, and even fell into losses. According to the financial report, as of 31st Mar, 2021, the cumulative loss of the pig futures hedging business conducted by Jin Xinnong amounted to 131 million yuan, including a floating loss of 31 million yuan and a liquidation loss of 100 million yuan[11].

Most head pig companies are still watching. At present, the trading liquidity of active domestic pig futures is low, and it is difficult to meet the large-scale demand of big enterprises. Transaction limits is at most 500 board lots for every member, which can translate into 
value of at most 73 thousand pigs in a month. It is far less than the sale amount of 1634 thousand by Muyuan in August, 2020. A large part of their assets is still violated.

\subsection{Expectation of the Hog Futures}

\subsubsection{A Transition Period}

At the initial stage of the issue of hog futures, China doesn't want its small farmers to be so quickly moved out of the market. However, farmers who are not able to participate in the futures market to sell contract does not corporate together at present. So there needs to be a intermediary agent to bring them together. To meet with such requirement, the combination of insurance and hog futures is created.

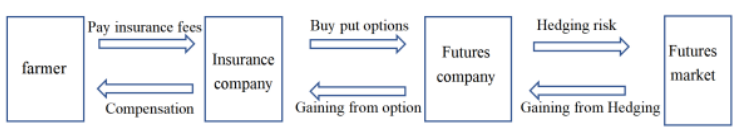

Figure 8 Operating Mechanism of the Insurance + Futures Mode[10]

As shown in Figure 8, Farmers buy insurance on hog prices from insurance companies, insurance companies buy over-the-counter put options from companies with futures trading licenses (maybe its subsidiaries), and then futures trading companies buy futures in the futures market to hedge the compensation risk caused by price fluctuations.

That is, farmers lose a small amount of money in exchange for a minimum guarantee of profits, and premiums are distributed between insurance companies and futures companies through the purchase of options. The existence of hog futures makes this income model which has less risk possible.

The operation model of 'insurance + futures' has contributed to the development of China's hog futures market and the stability of hog prices. Through this model, almost all farmers can be indirectly brought into the futures market for hedging. As a middleman, insurance companies can use futures to provide risk protection for many pig fa expand the size of the pig futures market, and play the role of pig futures in stabilizing the profit at the supply end and thus stabilizing the market price of pork. In this way, the liquidation of the futures market will be solved to some extent.

\subsubsection{Long-term Change}

In the long term, small farmers will either integrate into big ones or be moved out of the market to serve for big companies. Big pig companies act as industry integrators. By integrating or signing long-term production contracts with small producers, production integrators provide management services, piglets, medicine and other inputs to small producers. Small farmers mainly invest into labor and breeding equipment, and finally sell pigs to enterprises at a fixed price to earn.

When big companies dominate the market, raising procedure is standardized to ensure delivery quality of hogs. The hog futures market can surely become more active. As a response, position limits need to be relaxed due to a more centered market share. The trading unit needs be enlarged accordingly.

In addition, cash delivery can be considered with the price of hogs strictly related to quality of the hogs. Usage of lean meat ratio to evaluate is possible. When risks are reduced, trading limitations can also be removed in some periods to let the future price more related to stock price.

\section{CONCLUSION}

The issue of hog futures is an unprecedented trail in China to use the futures to help smooth the real economy. It undergoes careful discussion before coming out and is special in many contract design. As a tool to help participants along the supply chain to lock their profit, it aims to benefit both crop farmers, feeders and slaughter houses.

The price of corns and piglets contributes together positively to the price of live hogs and this can leads an increase in pork price. For estimation of the future, price of pork can influence that of corns, piglets and live hogs inversely. The price of piglets price of corns and price of live hogs.

Assuming such relationship will not change, we estimate the price of live hogs without issuing the hog futures. We find that the actual price is still in large violation and is going downward too drastically.

The reason can be the incapability for small farmers to participate and large enterprises are still waiting. It is expected that now it is a transition time in China to let farmers in the market through mode of insurance + futures. In the future, may be the market will integrate as a whole to let big companies take the role.

\section{REFERENCES}

[1] Farmers' Daily, 2021. How is the Hog Futures Invented. http://futures.hexun.com/

2021-03-16/203207142.html

[2] AgriPost, 2020. A Review of the Three Stages in the Development of American Hog Futures. https://www.powerpigs.net/index.php?3\&10830

[3] Dalian Commodity Exchange, 2020. Notice on the Promulgation of the Pig Futures Contract of Dalian Commodity Exchange and the Amendments to the Relevant Implementation Rules. http://www.dce.com.cn/dalianshang.cn/dalianshang pin/ywfw/jystz/ywtz/6262747/index.html 
[4] Nxin, 2021. Daily Price of the Live Hogs in China. http://hqb.nxin.com/nongbo/map/

[5] Founder Cifco Futures. How can Breeding Companies Use Futures to Manage Market Risk. http://futures.jrj.com.cn/2021/01/07105631646708. shtml

[6] Futrell, G.A., Mueller, A.G.,Grimes, G.. Understanding Hog Production and Price Cycles. https://swine.extension.org/understanding-hogproduction-and-price-cycles/

[7] Liang, X., Liu, X., Yang, F. (2015) Prediction model on chinese annual live hog supply and its application. Journal of Systems Science and Complexity, 28(2): 409-423.

[8] Liu, Y., Duan, Q., Wang, D., Zhang, Z., Liu, C. (2019) Prediction for hog prices based on similar sub-series search and support vector regression. Computers and Electronics in Agriculture, 157: 581 588.

[9] Carter, C.A., Mohapatra, S. (2008) How reliable are hog futures as forecasts. American Journal of Agricultural Economics, 90(2): 367-378.

[10] Zhang, H. (2020) The impact on the market and society of the model of "insurance+futures" in hog industry. Swine Industry Economics, 15(06):2022,32

[11] Jinxinnong. Reminder Announcement on the Company's Pig Futures Hedging Business All Liquidated.

http://data.eastmoney.com/notices/detail/002548/A N202106 241499771978.html 